\title{
Carbon Monoxide Attenuates Dextran Sulfate Sodium-Induced Colitis via Inhibition of GSK-3 $\beta$ Signaling
}

\author{
Md. Jamal Uddin,, Sun-oh Jeong, ${ }^{1}$ Min Zheng, ${ }^{1,2}$ Yingqing Chen, ${ }^{1}$ Gyeong Jae Cho, ${ }^{3}$ \\ Hun Taeg Chung, 1 and Yeonsoo Joe ${ }^{1}$ \\ ${ }^{1}$ School of Biological Sciences, University of Ulsan, Ulsan 680-749, Republic of Korea \\ ${ }^{2}$ Department of Thoracic and Cardiovascular Surgery, Affiliated Hospital of Yanbian University, Yanji 133000, China \\ ${ }^{3}$ Department of Anatomy, School of Medicine, Institute of Health Sciences, Gyeongsang National University, \\ Jinju 660-701, Republic of Korea
}

Correspondence should be addressed to Yeonsoo Joe; jcantibody@ulsan.ac.kr

Received 17 September 2013; Accepted 9 October 2013

Academic Editor: Alfredo Vannacci

Copyright (c) $2013 \mathrm{Md}$. Jamal Uddin et al. This is an open access article distributed under the Creative Commons Attribution License, which permits unrestricted use, distribution, and reproduction in any medium, provided the original work is properly cited.

\begin{abstract}
Endogenous carbon monoxide (CO) is produced by heme oxygenase-1 (HO)-1 which mediates the degradation of heme into CO, iron, and biliverdin. Also, $\mathrm{CO}$ ameliorates the human inflammatory bowel diseases and ulcerative colitis. However, the mechanism for the effect of $\mathrm{CO}$ on the inflammatory bowel disease has not yet been known. In this study, we showed that CO significantly increases survival percentage, body weight, colon length as well as histologic parameters in DSS-treated mice. In addition, CO inhalation significantly decreased DSS induced pro-inflammatory cytokines by inhibition of GSK-3 $\beta$ in mice model. To support the in vivo observation, TNF- $\alpha$, iNOS and IL-10 after CO and LiCl treatment were measured in mesenteric lymph node cells (MLNs) and bone marrow-derived macrophages (BMMs) from DSS treated mice. In addition, we determined that CO potentially inhibited GSK- $3 \beta$ activation and decreased TNF- $\alpha$ and iNOS expression by inhibition of NF- $\kappa$ B activation in LPS-stimulated U937 and MLN cells pretreated with CO. Together, our findings indicate that CO attenuates DSS-induced colitis via inhibition of GSK-3 $\beta$ signaling in vitro and in vivo. Importantly, this is the first report that investigated the molecular mechanisms mediated the novel effects of CO via inhibition GSK- $3 \beta$ in DSS-induced colitis model.
\end{abstract}

\section{Introduction}

Inflammatory bowel diseases (IBD) are a chronic and recurrent intestinal inflammation resulting from the transmural infiltration of neutrophils, macrophages, lymphocytes, and mast cells, ultimately giving rise to mucosal disruption and ulceration [1]. Furthermore, defects in epithelial barrier function and overproduction of proinflammatory cytokines such as IL-1 $\beta$, IL-6, IL-12p40, IL-23p19, TNF- $\alpha$ and IFN- $\gamma$ lead to tissue injury in intestine [2]. Additionally, upregulation of pro-inflammatory cytokines in IBD condition is mediated by NF- $\kappa \mathrm{B}$, a transcription factor [3]. In order to develop the various models of experimental IBD, dextran sulfate sodium (DSS) or trinitrobenzene sulfonic acid (TNBS) was administrated $[4,5]$. This model is characterized by acute tissue inflammation in the colon and mimics the pathology of human ulcerative colitis.
Endogenous carbon monoxide ( $\mathrm{CO}$ ) as the end product of heme oxygenase-1 (HO-1) activity has anti-inflammatory, antiapoptotic and cytoprotective properties [6]. Also, CO ameliorates active inflammation in an experimental model of chronic IBD $[7,8]$. Further, CO has showen beneficial effects in ischemia/reperfusion injury $[9,10]$, pulmonary inflammation [11], and sepsis [12]. In case of tracheal transplantation in mice, CO inhibits NF- $\kappa$ B binding and iNOS expression [13]. In addition, CO-releasing molecules-2 (CORM)-2 which can deliver $\mathrm{CO}$ in the biological system have been found to reduce the inflammatory response by inhibition of $\mathrm{NO}$ and tumor necrosis factor (TNF- $\alpha$ ) expression in mouse macrophages [14]. In particular, CORM-2 prevented the inflammation in murine colitis by inhibition of cytokine production [15]. Interestingly, recent studies have demonstrated that CO ameliorates active inflammation in an experimental model of 
chronic IBD or IL-10-deficient (-/-) mice, through induction of $\mathrm{HO}-1$ [7], but the precise mechanism remains unclear.

Glycogen synthase kinase-3 (GSK-3), a serine-threonine protein kinase, plays a vital role in glycogen metabolism, as well as regulation of cellular functions like control of cell division and apoptosis [16]. GSK3 is a constitutively active serine/threonine protein kinase having GSK- $3 \alpha$ and GSK-3 $\beta$ isoforms. GSK-3 $\beta$ activity is inhibited by phosphorylation of serine 9 residue [17] and mediates the NF- $\kappa \mathrm{B}$ activity [18]. Also, selective inhibitors of GSK- $3 \beta$ were found to inhibit the inflammation and tissue injury due to downregulation of NF$\kappa \mathrm{B}$ activity in acute colitis in rat [19]. On the one hand, GSK$3 \beta$ expression was suppressed by HO-1 inducer hemin [20]. Therefore, $\mathrm{CO}$ as an end product of $\mathrm{HO}-1$ catalytic reaction for breakdown of the heme moiety may inhibit the activation of GSK-3 $\beta$.

The underlying mechanism of $\mathrm{CO}$ in the regulation of inflammatory response is not clear yet especially in DSSinduced colitis model. Therefore, we suggest that the therapeutic effects of CO on DSS-induced colitis result from the inhibition of GSK- $3 \beta$ and NF- $\kappa$ B activation.

\section{Materials and Methods}

2.1. Reagents. Dextran sulfate sodium salt (DSS) was purchased from MP Biomedicals (LLC, France). Lipopolysaccharides (LPS), lithium chloride ( $\mathrm{LiCl}$ ), and tricarbonyldichlororuthenium (II) dimer (CORM2) were purchased from Sigma Aldrich (St. Louis, MO, USA). Phospho(p)-GSK-3 $\beta$ (serine9), GSK-3 $\beta$, NOS2 (iNOS), p$\mathrm{IkB}$, and IkB were obtained from Santa Cruz Biotechnology (Santa Cruz, CA, USA). All other chemicals were obtained from Sigma-Aldrich.

2.2. Animals. Seven-week-old male C57BL/6 mice were obtained from ORIENT (Pusan, Korea). The mice were maintained in standard housing cages under specific pathogenfree conditions at $22^{\circ} \mathrm{C}$ and access to drinking water ad libitum. Mice were allowed to drink with or without 3\% DSS water for 6 days and then mice were inhaled with or without $\mathrm{CO}$ (250 ppm) for $4 \mathrm{~h}$ or injected with $\mathrm{LiCl}(200 \mathrm{mg} / \mathrm{kg}$, i.p.) on daily basis for 10 or 12 days. All mice were being fed with standard laboratory chow ad libitum at all times. Control mice were given only water. Water and chow consumption was comparable between DSS and control groups, both before and during the induction of colitis. Body weight was recorded daily and survival percent was monitored at 10 and 12 days respectively. After 10 days of $\mathrm{CO}$ or $\mathrm{LiCl}$ treatment, mice were sacrificed and colons from all mice were collected for histological and molecular assessment of inflammation. Experiments with mice were approved by the Animal Care Committee of the University of Ulsan.

2.3. Isolation and Culture of Bone Marrow Macrophages (BMMs) and Mesenteric Lymph Node Cells (MLNs). Six- to 7-week-old C57BL/6 mice were provided with or without $3 \%$ DSS water for 6 days. BMMs were isolated as previously described [21]. After sacrificing the mice, femora and tibiae were carefully taken out and dissected free of adherent soft tissue. Bone marrow cells were collected by flushing the cavity by slowly injecting MEM- $\alpha$ medium (Hyclone, Loan, UT, USA). Cells were washed with PBS twice, and then the cells were taken in MEM- $\alpha$ medium containing $10 \%$ FBS, 50 units/mL penicillin, $50 \mu \mathrm{g} / \mathrm{mL}$ streptomycin (Gibco, Grand Island, NY, USA). Cells were cultured in $10 \mathrm{~cm}$ tissue culture dishes at an amount of $2 \times 10^{6}$ cells/dish and mouse macrophage colony stimulating factor (M-CSF, $10 \mathrm{ng} / \mathrm{mL}$, BioSource, Camarillo, CA, USA) was added to differentiate BMMs. Three days later, nonadherent cells were removed and adherent cells (immature BMM) were suspended in fresh MEM- $\alpha$ with M-CSF and used for experiment. On the other hand, mesenteric lymph nodes were also isolated from mice treated with or without 3\% DSS and MLNs were pressed through a cell strainer (Falcon 2340; BD Biosciences, San Jose, CA, USA) to get single cells. Cells were collected on DMEM containing 10\% FBS and antibiotics. After washing with medium, cells were counted and used for subsequent experiment. Cells were treated with CORM2 and $\mathrm{LiCl}$ and then stimulated with or without LPS $(1 \mu \mathrm{g} / \mathrm{mL})$ for designated time points.

2.4. Cell Culture. U937 cells were cultured in DMEM in addition to $10 \% \mathrm{FBS}$ and $1 \%$ penicillin streptomycin at $37^{\circ} \mathrm{C}$ in $5 \% \mathrm{CO}_{2}$ until $75-80 \%$ confluence. After that, cells at the rate of $5 \times 10^{5} / \mathrm{mL}$ were splited in 6 -well plates and incubated for $18 \mathrm{~h}$. Then cells were pretreated with CORM2 or $\mathrm{LiCl}$ and then treated with or without LPS $(1 \mu \mathrm{g} / \mathrm{mL})$ for $24 \mathrm{~h}$. After incubation, cells were harvested for western blotting and RTPCR, and supernatant was collected to perform ELISA assay (R\&D systems, Inc., Minneapolis, MN, USA) for measuring the level of TNF- $\alpha$ production as well.

2.5. Histological Analysis. After sacrificing the mice, the entire colon was dissected and flushed with ice-cold PBS. For histological analysis, mice colons were fixed in 10\% neutralbuffered formalin for $24 \mathrm{~h}$ at room temperature, and paraffinembedded tissue sections were stained with HE (hematoxylin and eosin) using standard techniques.

2.6. Western Blotting. Colon tissue or cell extracts were prepared using lysis buffer containing RIPA buffer, protease inhibitor, and phosphatase inhibitors. Protein concentration in the lysate was measured by BCA assay (Pierce Biotechnology Inc., Rockford, IL, USA). An equal amount of protein was subjected to electrophoresis and then proteins were transferred to polyvinylidene difluoride (PVDF) membrane. After transfer, the membranes were blocked with $5 \%$ nonfat milk in PBS containing $0.1 \%$ Tween 20 (PBS-T) for $20 \mathrm{~min}$ and incubated at $4^{\circ} \mathrm{C}$ overnight with primary antibodies and followed by secondary antibodies conjugated with horseradish peroxidase for $\mathrm{pGSK}-3 \beta$, GSK- $3 \beta$, $\mathrm{pI} \kappa \mathrm{B}, \mathrm{I} \kappa \mathrm{B}$, iNOS and $\beta$ actin. Enhanced chemiluminescence (ECL) western blotting detection system (GE Healthcare Life Sciences, Buckinghamshire, UK) was used to visualize the protein bands.

2.7. Reverse Transcription-Polymerase Chain Reaction (RT$P C R)$. Total RNA was extracted from colon tissue or cell 
pellet using TRIzol reagent (Invitrogen, CA, USA) according to the manufacturer's instructions. In short, $2 \mu \mathrm{g}$ of total RNA was used to make cDNA by using M-MLV reverse transcriptase (Promega Corporation, WI, USA) and oligo (dT) 15 primer (Promega Corporation, WI, USA). The resulted CDNA was subjected to PCR for mouse GAPDH (f-aggccggtgctgagtatgtc, r-tgcctgcttcaccttct, 530 bp), $18 \mathrm{~S}$ (f-cagtgaaactgcgaatggct, r-tgccttccttggatgtggta, $397 \mathrm{bp}$ ), iNOS (f-ccaccttggtgaagggactgagct, r-gctgcggggagccattttggt, $381 \mathrm{bp}$ ), TNF- $\alpha$ (f-agcccacgtcgtagcaaaccaccaa, r-acacccattcccttcacagagcaat, $421 \mathrm{bp}$ ) and IL-10 (f-gacaataactgcacccactt, rtcaaatgctccttgatttct, $250 \mathrm{bp}$ ); and human GAPDH (f-ccacccatggcaaattccatggca, r-tctagacggcaggtcaggtccacc, 520 bp), iNOS (f-cagtacgtttggcaatggagactgc, r-ggtcacattggaggtgtagagcttg, 340 bp), t-bet (f-gctgtgcaggtgttgagcc, r-cataactgtgttcccgaggtgtc), and GATA-3 (f-gcctgtgcaaaagagatttcagat, r-tgattcacagagcatgtaggcc). GAPDH or $18 \mathrm{~S}$ was used as internal loading control. The PCR products were detected on $2 \%$ agarose gels using digital gel documentation set.

2.8. Enzyme-Linked Immunosorbent Assay (ELISA). U937 and MLN cells were incubated overnight on 6-well plate and then pretreated with CORM2 and $\mathrm{LiCl}$ for $30 \mathrm{~min}$ followed by stimulated with LPS $(1 \mu \mathrm{g} / \mathrm{mL})$ for $24 \mathrm{~h}$. Supernatant was collected from different experimental samples and levels of TNF- $\alpha$ were assayed by using human ELISA kit (BD Biosciences, San Diego, CA, USA) in U937 cells and mouse ELISA kit (R\&D systems) in MLN cells.

2.9. Statistical Analysis. Results are expressed as the means \pm SD. Statistical analysis was performed with the GraphPad Prism software version 5 (GraphPad Software Inc., San Diego, CA, USA). Differences in the data among the groups were analyzed using one-way ANOVA followed by Tukey's post hoc test.

\section{Results}

3.1. CO Ameliorates Survival, Body Weight, and Colon Length in DSS-Induced Colitis. In this study, colitis was induced by providing mice with 3\% DSS water for 6 days. To examine the in vivo effects of $\mathrm{CO}$ or GSK-3 $\beta$ inhibitor $(\mathrm{LiCl})$ on survival of DSS-induced colitis mice, we inhaled mice with $\mathrm{CO}$ (250 ppm) for $4 \mathrm{~h}$ or administrated $\mathrm{LiCl}(200 \mathrm{mg} / \mathrm{kg}$, i.p.) on daily basis to mice for more 6 days. We found that mice from DSS group had $0 \%$ survival rate after 11 days of DSS treatment. On the other hand, the mice treated with $\mathrm{CO}$ or $\mathrm{LiCl}$ in the presence of the DSS had significantly higher rate of survival compared to DSS group (Figure 1(a)). Similarly, to determine the in vivo effects of $\mathrm{CO}$ or GSK-3 $\beta$ inhibitor $(\mathrm{LiCl})$ on body weight of DSS-induced colitis mice, CO (250 ppm) inhalation for $4 \mathrm{~h}$ or administrated $\mathrm{LiCl}(200 \mathrm{mg} / \mathrm{kg}$, i.p.) on daily basis was performed. Interestingly, we found those mice treated with $\mathrm{CO}$ or $\mathrm{LiCl}$ in the presense of the DSS had significantly higher body weight compared to that of DSS group (Figure 1(b)). According to the data, preventive treatment with $\mathrm{CO}$ is capable of increasing the survival rate as well as body weight of mice with colitis induced by DSS. At prescheduled time points, mice were killed, and the entire colon of mice were taken and then imaging was performed using a light imaging box and colon length was determined using a measuring scale. We found that DSS induced colitis significantly shortened colon length and, inhalation of $\mathrm{CO}$ or LiCl administration significantly recovered DSS effects (Figures 1(c) and 1(d)), suggesting beneficial effects of $\mathrm{CO}$ on DSS-induced colitis where inhibition of GSK-3 $\beta$ is involved.

3.2. CO Attenuates Experimental Colitis as Measured by Histology and Inflammatory Cytokines in Colon. To know the effect of CO on GSK-3 $\beta$ and DSS-induced colitis, we inhaled mice with $\mathrm{CO}(250 \mathrm{ppm})$ for $4 \mathrm{~h}$ or administrated $\mathrm{LiCl}(200 \mathrm{mg} / \mathrm{kg}$, i.p.) on daily basis to mice for more 4 days. Mice were sacrificed at designated time points; the entire colons were dissected and fixed in $10 \%$ formalin. We have characterized the histological features of paraffin-embedded tissue sections from mice colons by $\mathrm{H} \& \mathrm{E}$ staining. The histological features of the colons of $\mathrm{CO}$ treated and $\mathrm{LiCl}$ treated group were better than those of DSS-treated group (Figure 2(a)). To confirm the histological results, we checked mRNA expression patterns of TNF- $\alpha$, iNOS and IL-10 in colon tissue obtained from DSS induced colitis mice following administration of $\mathrm{CO}$ and $\mathrm{LiCl}$. Interestingly, $\mathrm{CO}$ or $\mathrm{LiCl}$ was found to be involved with significant suppression of TNF$\alpha$, iNOS and at the same time IL-10 mRNA level was found to significantly increase in colon tissue in vivo (Figure 2(b)). To further confirm the results, expression pattern of pGSK-3 $\beta$ and iNOS protein in colon tissue obtained from DSS-induced colitis mice following administration of $\mathrm{CO}$ and $\mathrm{LiCl}$ was examined. We found that $\mathrm{CO}$ or $\mathrm{LiCl}$ significantly increased expression of $\mathrm{pGSK}-3 \beta$ and at the same time iNOS protein was found to decrease in colon tissue in vivo (Figure 2(c)). Results indicating the role of CO in inhibition of DSSinduced colitis are mediated through inhibition of GSK-3 $\beta$ activation.

3.3. CO Regulates the Production of Cytokines in MLNs and BMMs from DSS-Induced Colitis. Colitis was induced to mice through providing 3\% DSS in drinking water for 6 days. After 6 days, mice were sacrificed to collect mesenteric lymph node and bone marrow. To investigate the effect of $\mathrm{CO}$ or $\mathrm{LiCl}$ on colitis-induced inflammatory cytokines, MLNs and BMMs were treated with CORM2 $(100 \mu \mathrm{M})$ or $\mathrm{LiCl}(20 \mathrm{mM})$ for $6 \mathrm{~h}$ and harvested cells were subjected for mRNA analysis by RT-PCR. Data showed that CORM2 and GSK-3 $\beta$ inhibitor significantly downregulated DSS induced proinflammatory cytokines such as TNF- $\alpha$ and iNOS mRNA level by increasing mRNA level of IL-10 in MLNs (Figure 2(d)) and BMMs (Figure 2(e)) respectively. To confirm the role of GSK-3 signaling in CORM2 or LiCl-treated MLNs and BMMs, we detected the levels of pGSK-3 $\beta$ using western blot analysis. The expression of $\mathrm{pGSK}-3 \beta$ inhibited by DSS treatment was increased with CORM2 or $\mathrm{LiCl}$ in MLNs (Figure 2(f)) and BMMs (Figure 2(g)). Also, according to the report of Marques et al. [22], HO-1/CO system could regulate the Th1/Th2 profile. To investigate the association between GSK$3 \beta$ signaling and Th1/Th2 profiling, we analyzed the levels of GATA-3 for Th2 cells and t-bet for Th1 cells using real-time PCR analysis. 


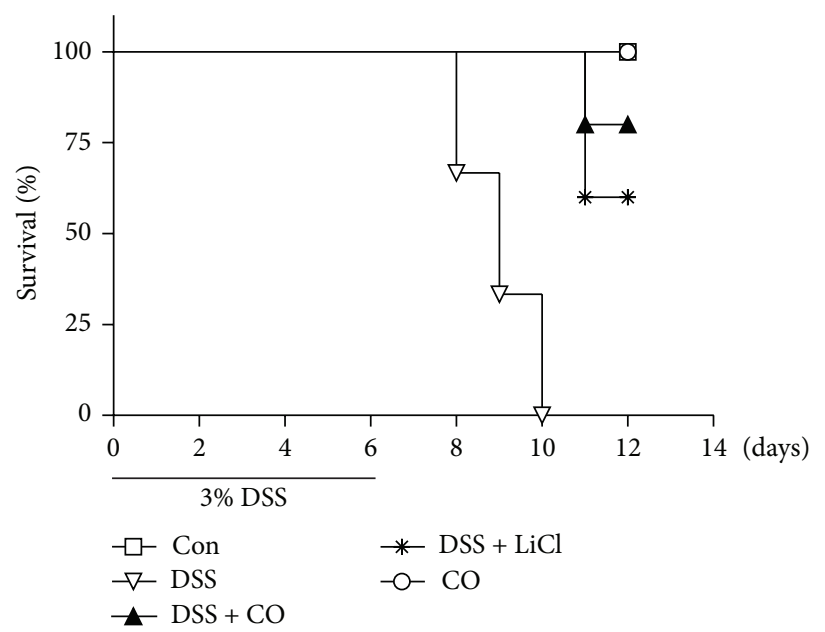

(a)

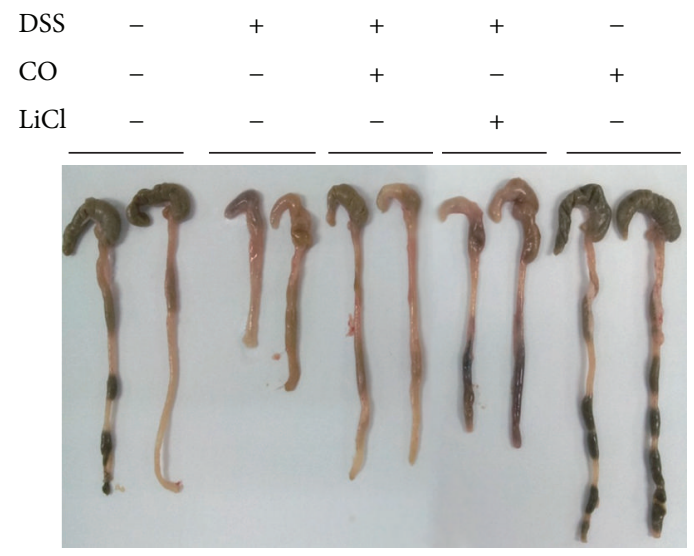

(c)

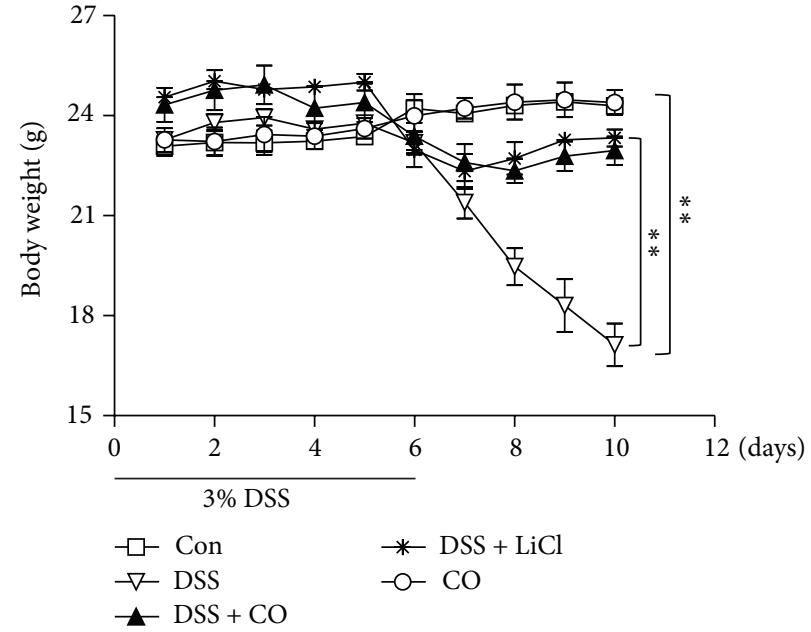

(b)

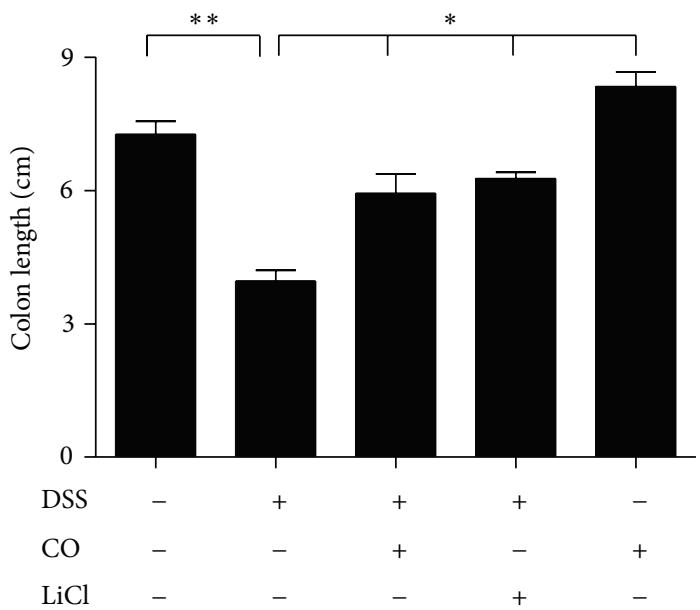

(d)

FIGURE 1: CO attenuates DSS-induced experimental colitis as measured by survival, body weight, and colon length. Mice were administrated with 3\% DSS with drinking water for 6 days and CO (250 ppm) inhalation for 4 h daily and injection of $\mathrm{LiCl}(200 \mathrm{mg} / \mathrm{kg}$, i.p) was performed daily for more 4 or 6 days. (a) Survival percent was measured at day 12. (b) Body weight was measured at day 10. (c) and (d) Colon length. (c) Representative images of 3 tests conducted in each group. (d) Data are mean \pm SD for 3 mice. Con: Control, DSS: dextran sufate sodium salt and Data represents mean $\pm \mathrm{SEM},{ }^{*} P<0.05,{ }^{* *} P<0.01$.

The levels of GATA-3 were increased by LiCl or CORM2 treatment (Figure 2(h)). DSS-induced t-bet levels were suppressed by CORM2 or LiCl treatment (Figure 2(i)). Therefore, these data suggested that $\mathrm{CO}$ mediates inhibition of colitis-induced proinflammatory cytokines and regulation of Th1/Th2 profile via inhibition of GSK- $3 \beta$ activation.

3.4. CO Controls GSK-3ß Signaling in Human Macrophage Cell Lines and Mesenteric Lymph Node Cells (MLNs). GSK3 is a constitutively active serine/threonine protein kinase having GSK- $3 \alpha$ and GSK- $3 \beta$ isoforms. GSK- $3 \beta$ activity is tightly controlled by phosphorylation of regulatory serine 9 leading to its inhibition [17]. To monitor the CO effects on GSK$3 \beta$ signaling, U937 cells were time and dose dependently treated with CORM2 and western blotting was performed.
CORM2 strongly increased the pGSK-3 $\beta$ in the time-and dose dependent manners (Figures 3(a) and 3(b)). To confirm the in vivo observation of whether $\mathrm{CO}$ effect is mediated through inhibition of GSk-3 $\beta$, U937 monocytes were pretreated with CORM2 $(100 \mu \mathrm{M})$ and $\mathrm{LiCl}(20 \mathrm{mM})$ for $30 \mathrm{~min}$ and then cells were stimulated with LPS $(1 \mu \mathrm{g} / \mathrm{mL})$ for $30 \mathrm{~min}$ and harvested cells were subjected to protein analysis for inactive form of GSK $-3 \beta$ and activity of NF- $\kappa$ B. Interestingly, we observed that LPS mediated activation of GSK-3 $\beta$ was inhibited with treatment of CORM2 or $\mathrm{LiCl}$ by increasing pGSK-3 $\beta$ expression (Figure $3(\mathrm{c})$ ). The influence of GSK- $3 \beta$ inhibition on the activities of transcription factors, NF- $\kappa \mathrm{B}$, was assessed, as it is known to regulate cytokine-mediated inflammatory responses [23]. Further, LPS increased NF- $\kappa$ B activity downstream of GSK- $3 \beta$ by I $\kappa$ B 

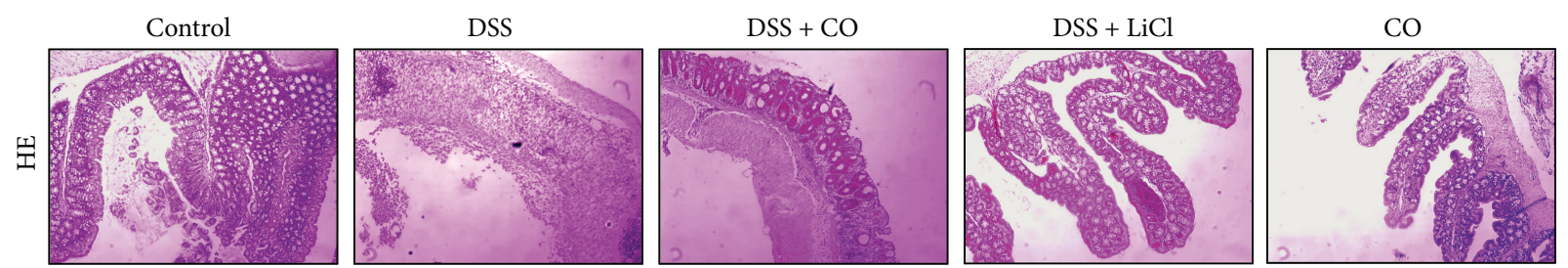

(a)

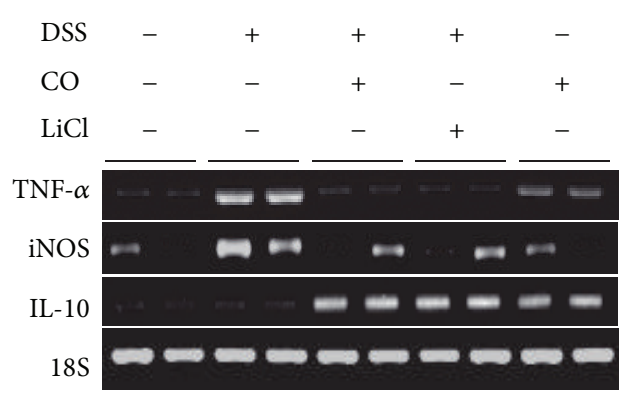

(b)

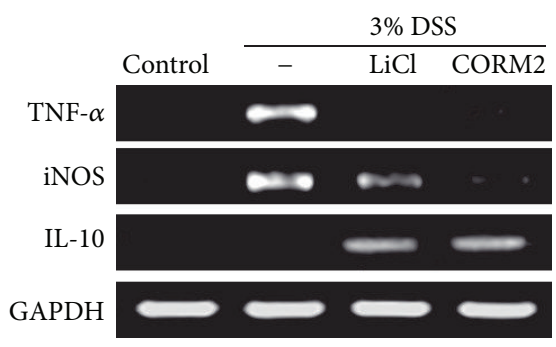

(d)

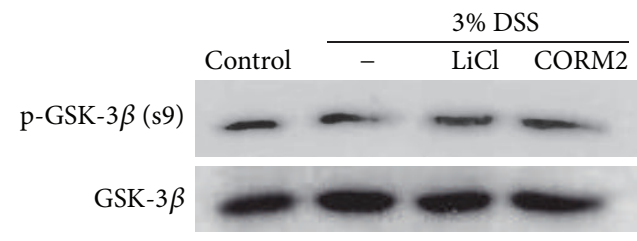

(f)

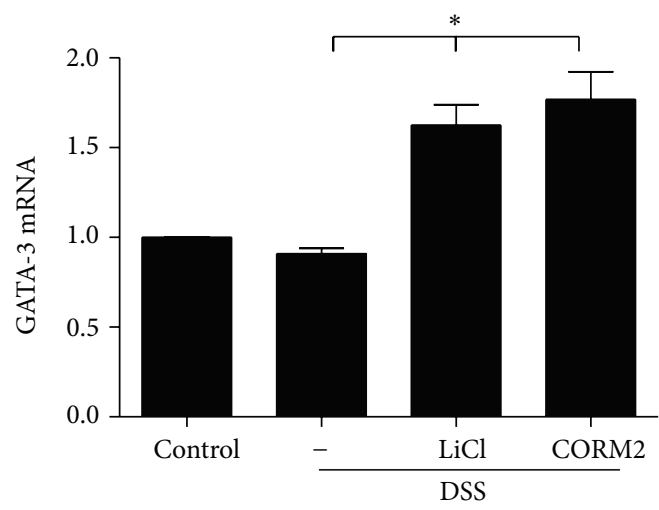

(h)

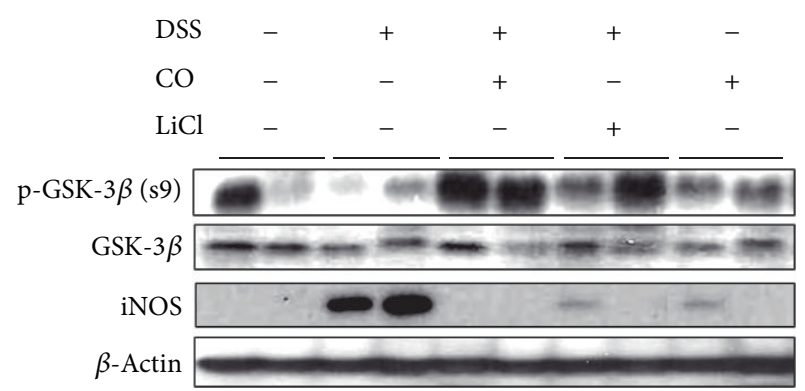

(c)

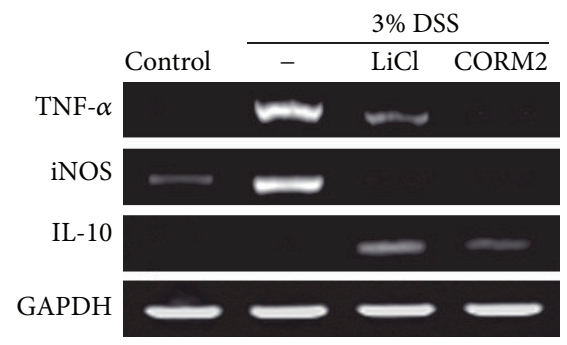

(e)

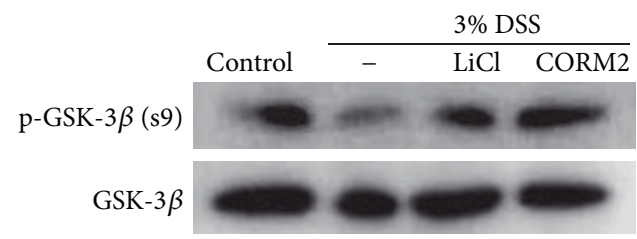

(g)

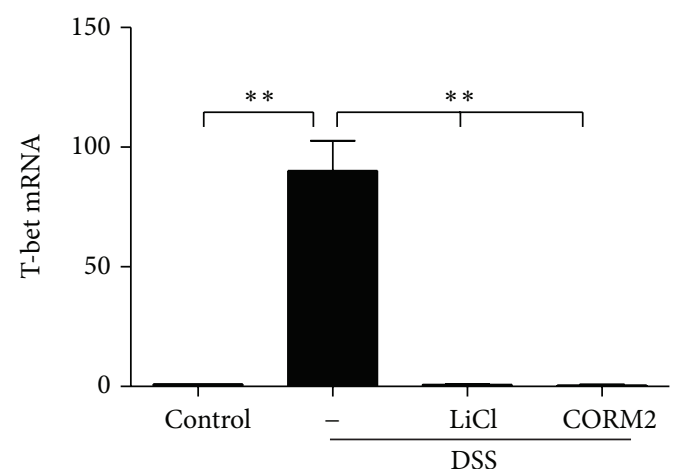

(i)

FIGURE 2: CO attenuates experimental colitis as measured by histology in colon and inflammatory cytokines in colon, MLNs, and BMMs. Mice were administrated with $3 \%$ DSS with drinking water for 6 days and $\mathrm{CO}(250 \mathrm{ppm})$ inhalation for $4 \mathrm{~h}$ daily and injection of LiCl (200 mg/kg, i.p) was performed daily for more 4 days. (a) Colon sections were subjected to H\&E staining. (b) TNF- $\alpha$, iNOS, and IL-10 mRNA levels were detected from colon tissue by RT-PCR. (c) iNOS and pGSK-3 $\beta$ protein levels were measured from colon tissue by western blotting. To detect the levels of cytokines in MLNs and BMM cells, mice were treated with 3\% DSS solution for 6 days and isolated MLN and BMM cells were treated with CORM2 $(100 \mu \mathrm{M})$ or $\mathrm{LiCl}(20 \mathrm{mM})$ for $6 \mathrm{~h}$. The levels of TNF- $\alpha$, iNOS, and IL-10 mRNA were performed by using RT-PCR in MLN cells (d) and BMMs (e) and the levels of pGSK-3 $\beta$ were detected with western blot in MLN (f) and BMM (g) cells. Also, mRNA levels of GATA-3 (h) and t-bet (i) were performed by using real-time RT-PCR in MLN cells. Data represents mean \pm SEM, ${ }^{*} P<0.05,{ }^{* *} P<0.01$, and ${ }^{* * *} P<0.001$ 


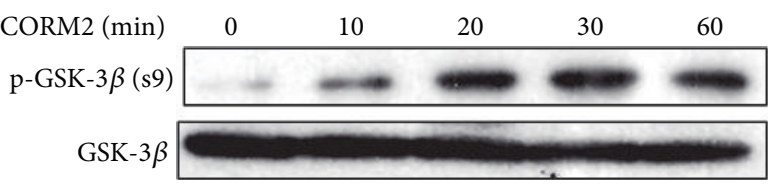

(a)

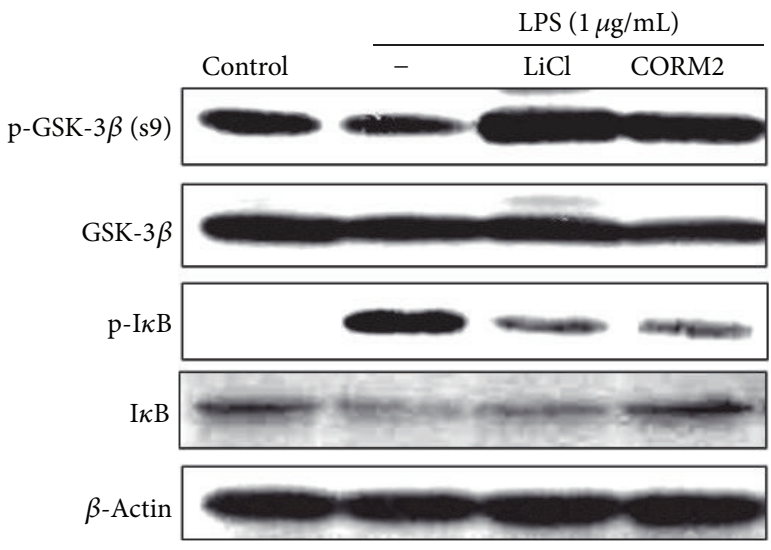

(c)

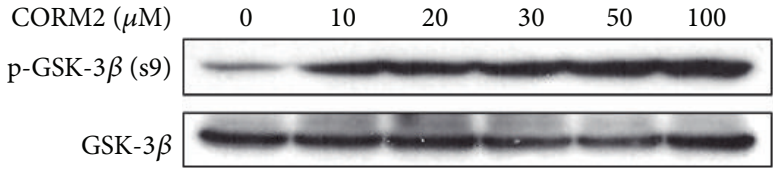

(b)

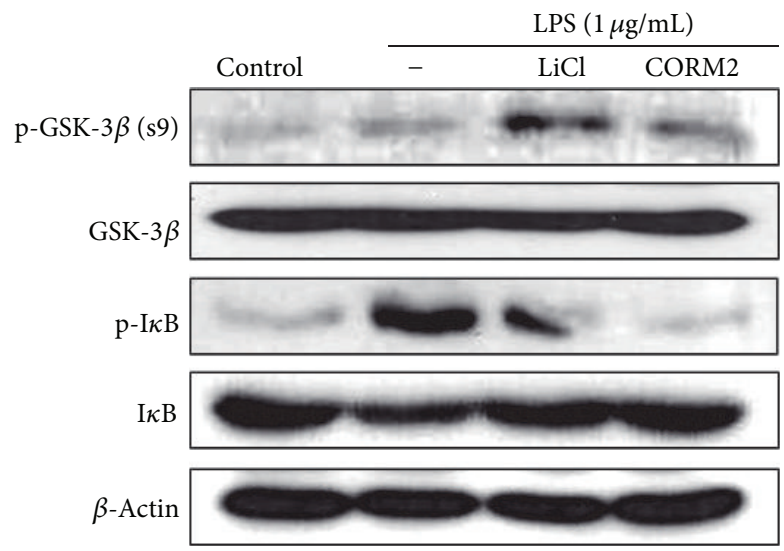

(d)

FIGURE 3: CO attenuates expression of GSK-3 $\beta$ signaling in human macrophage cell lines and MLNs. (a) U937cells were incubated with CORM2 $(100 \mu \mathrm{M})$ for various time periods $(0,10,20,30$, and $60 \mathrm{~min})(\mathrm{b})$ Cells were treated with CORM2 in a dose dependent manner $(0,10$, $20,30,50$, and $100 \mu \mathrm{M})$ for $30 \mathrm{~min}$. (c) U937cells were preincubated with CORM2 (100 $\mu \mathrm{M})$ and $\mathrm{LiCl}(20 \mathrm{mM})$ for 30 min and then stimulated with LPS $(1 \mu \mathrm{g} / \mathrm{mL})$ for $30 \mathrm{~min}$. (d) MLNcells were preincubated with CORM2 $(100 \mu \mathrm{M})$ and LiCl $(20 \mathrm{mM})$ for 30 min and then stimulated with LPS $(1 \mu \mathrm{g} / \mathrm{mL})$ for $30 \mathrm{~min}$. Protein expressions of $\mathrm{pGSK}-3 \beta$ and $\mathrm{pI} \kappa \mathrm{B}$ were detected by western blotting.

activation and CORM2 and LiCl significantly abrogated LPS effects (Figure 3(c)). To confirm the above and gain insight whether GSK-3 $\beta$ inhibition directly impairs the function of intestinal immune cells, in vitro stimulation experiments were performed with MLN cells. Similarly, we found that LPS stimulated GSK $-3 \beta$ and NF- $\kappa$ B activation was potentially reduced by CORM2 as well as GSK-3 $\beta$ inhibitor in MLN cells (Figure $3(\mathrm{~d})$ ). The data presents that anti-inflammatory effect of $\mathrm{CO}$ is mediated by inhibition of GSK-3 $\beta$ and its downstream NF- $\kappa$ B activation.

3.5. CO Downregulates TNF- $\alpha$ and iNOS Expression via Inhibition of GSK-3 $\beta$ Signaling. GSK-3 $\beta$ positively regulates the most important transcription factor in immune system NF$\kappa \mathrm{B}$, which controls proinflammatory responses $[24,25]$. To obtain insight into the underlying mechanism responsible for inhibition of inflammatory effect of GSK-3 $\beta$ by CO in vitro, we pretreated U937 monocytes with CORM2 $(100 \mu \mathrm{M})$ and $\mathrm{LiCl}(20 \mathrm{mM})$ for $30 \mathrm{~min}$, and then cells were stimulated with LPS $(1 \mu \mathrm{g} / \mathrm{mL})$ for $24 \mathrm{~h}$ and harvested cells were subjected to protein and mRNA analysis of TNF- $\alpha$ and iNOS. Data showed that CORM2 and LiCl significantly decreased LPS induced TNF- $\alpha$ and iNOS expression (Figures 4(a), 4(b), and $4(\mathrm{c})$ ). To confirm CO effects on pro-inflammatory cytokines in relation to GSK-3 $\beta$, we used MLN cells and pretreated them with CORM2 $(100 \mu \mathrm{M})$ or $\mathrm{LiCl}(20 \mathrm{mM})$ for $30 \mathrm{~min}$ and then cells were incubated with LPS $(1 \mu \mathrm{g} / \mathrm{mL})$ for $24 \mathrm{~h}$. Likewise, CORM2 and $\mathrm{LiCl}$ significantly decreased LPSinduced TNF- $\alpha$ and iNOS expression in MLN cells as well (Figures 4(d) and 4(e)). Results from U937 and intestinal immune cells indicate that anti-inflammatory effects of $\mathrm{CO}$ took place by inhibition of GSK-3 $\beta$.

\section{Discussion}

Underlying mechanism behind the pathogenesis of the human IBD is very complex due to the involvement of various factors like genetic, immunologic, and environmental factors [26, 27]. Recently, carbon monoxide (CO) is well known to have various functions in immunomodulation, anti-inflammation, and physiological homeostasis [28]. In addition, CO was found to have protective effects against ulcerative colitis [7] and chronic intestinal inflammation [29], respectively. Exogenous $\mathrm{CO}$ provides the anti-inflammatory response in case of hyperoxia condition [14], organ transplantation [30], and ischemia reperfusion (I/R) injury [31, 32]. Furthermore, the protective effects of $\mathrm{CO}$ have been investigated in intestinal inflammation both in vitro and in vivo. Thus, $\mathrm{CO}$ can be a potential therapeutic option in case of IBD due to its effectiveness in alleviating intestinal inflammation and augment mucosal compensation $[33,34]$. However, molecular mechanism behind the beneficial effects of CO in intestinal inflammation is not yet clear. In this study, we showed that DSS-induced colitis is attenuated by COmediated inhibition of GSK-3 $\beta$ signaling in experimental mice model.

GSK $-3 \beta$ is a constitutively active serine/threonine protein kinase that is involved in a large number of cellular functions [17] and is capable of regulating the activity of NF- $\kappa \mathrm{B}$, a key transcription factor for proinflammatory immune responses 


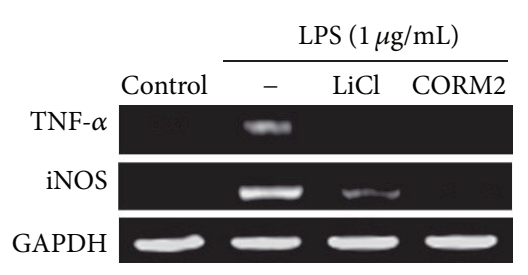

(a)

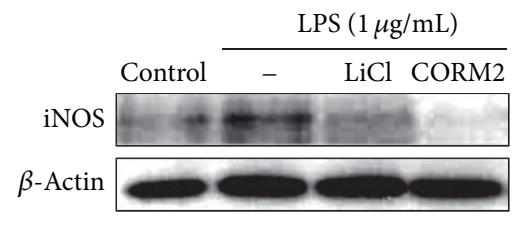

(b)

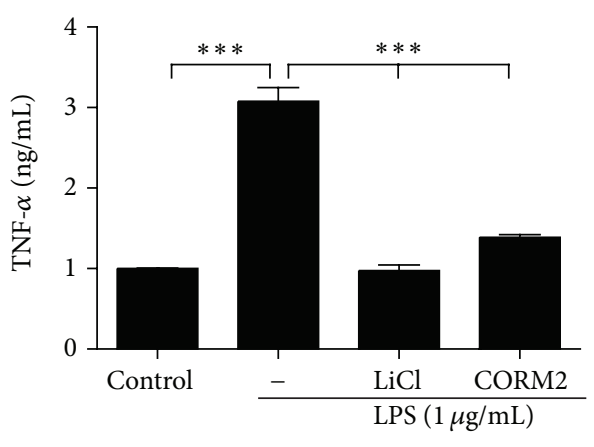

(c)

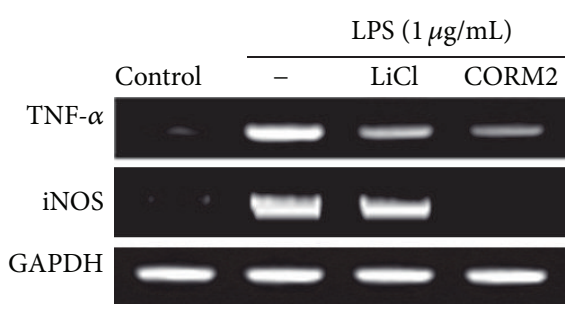

(d)

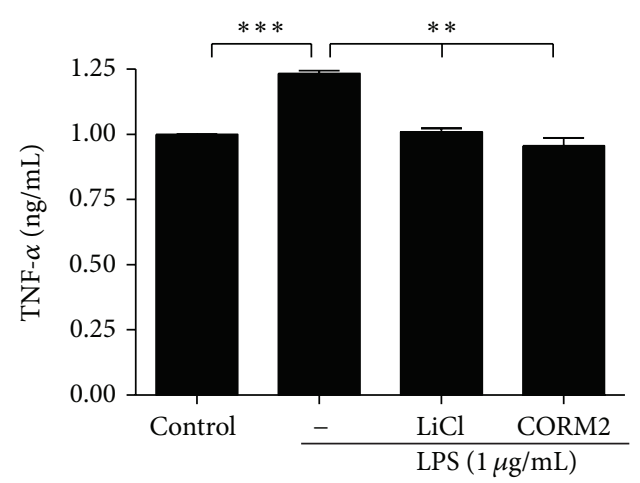

(e)

FIgURE 4: CO downregulates TNF- $\alpha$ and iNOS expression via inhibition of GSK-3 $\beta$ signaling. (a) to (c) U937 cells were pretreated with CORM2 $(100 \mu \mathrm{M})$ and $\mathrm{LiCl}(20 \mathrm{mM})$ for $30 \mathrm{~min}$ followed by stimulation with LPS $(1 \mu \mathrm{g} / \mathrm{mL})$ for $24 \mathrm{~h}$. (a) TNF $\alpha$ and iNOS mRNA expression was measured by RT-PCR, (b) iNOS protein expression was measured by western blotting, and (c) supernatant was collected and TNF- $\alpha$ protein level was measured by ELISA. (d) to (e) MLN cells were pre-incubated with CORM2 $(100 \mu \mathrm{M})$ and $\mathrm{LiCl}(20 \mathrm{mM})$ for $30 \mathrm{~min}$ and then stimulated with LPS $(1 \mu \mathrm{g} / \mathrm{mL})$ for $24 \mathrm{~h}$. (d) iNOS and TNF- $\alpha$ mRNA expression was measured by RT-PCR, and (e) Supernatant was used to measure TNF- $\alpha$ protein level by ELISA. The representative band or blot is shown. Data represents mean \pm SEM, ${ }^{*} P<0.05,{ }^{* *} P<0.01$, ${ }^{* * *} P<0.001$.

[35]. Inhibition of GSK-3 $\beta$ signaling has been reported to reduce experimental colitis in rat [19]. Increased GSK-3 $\beta$ activity was found to decrease IL-10 production leading to dampen inflammatory processes in intestinal immune cells [36] and macrophages [37]. Further, rat model of colitis exhibits many of the macroscopic, histological, and immunological features of inflammatory bowel disease (IBD) with neutrophilic involvement [19]. In our study, we found that CO and GSK-3 $\beta$ inhibitor significantly improved the survival of DSS-treated mice by increasing body weight, colon length and histological parameters, suggesting that $\mathrm{CO}$ inhalation improved experimental colitis by inhibition of GSK-3 $\beta$ signaling. However, DSS- [38] and TNBS- [39, 40] induced colitis have been found to be increased in colonic TNF- $\alpha$ levels. Further, CO ameliorated colitis in IL$10-/-[41]$ and TCR $\alpha-/-$ mice and therapeutic effects of CO correlated with induction of IL-10 $[8,42]$. In the present study, $\mathrm{CO}$ and LiCl significantly decreased DSS-induced TNF- $\alpha$ and iNOS and in the same time inactive form of GSK-3 $\beta$ increased in colonic tissues in mice in vivo. Additionally, ex vivo experiment showed that DSS-induced TNF- $\alpha$ and iNOS expression was reduced by CORM2 and $\mathrm{LiCl}$ by increasing IL-10 in MLNs and BMMs. Results from in vivo and ex vivo experiments indicate regulation of GSK- $3 \beta$ by CO in DSSinduced experimental mice model.

GSK-3 $\beta$ inhibitors reduced the systemic inflammatory response, tissue injury, and the phosphorylation of NF$\kappa \mathrm{B}$ and its downstream genes in the lung tissue of rats [43]. To confirm the in vivo data regarding regulation of colitis and involvement of CO and GSK-3 $\beta$, we did some in vitro experiments with U937 monocytes and MLN cells. CORM2 potentially increased the pGSK- $3 \beta$ with time- and dose-dependent manners. In addition, CORM2 and $\mathrm{LiCl}$ significantly decreased LPS-induced NF- $\kappa \mathrm{B}$ activation by increasing I $\kappa$ B and pGSK-3 $\beta(\operatorname{ser} 9)$ in U937 as well as MLN cells as described [44].

Proinflammatory cytokines play an important role in the inflammatory events in IBD. Blockade of GSK- $3 \beta$ attenuates TLR-mediated excessive proinflammatory cytokines and constitutes a promising therapeutic option for reducing intestinal immune reactions toward the luminal flora in inflammatory bowel disease [45]. In our observation, it is provided that TLR4 ligand, and LPS-induced inflammatory responses (TNF- $\alpha$, iNOS) were downregulated by CORM2 and $\mathrm{LiCl}$ treatment in U937 and MLN cells. Data presents that CO inhibits inflammatory cytokines induced by LPS via inhibition of GSK-3 $\beta$ signaling in vitro as well. 
To our knowledge, these results are the first to characterize anti-inflammatory properties of $\mathrm{CO}$ via inhibition of GSK-3 $\beta$ in a DSS-mediated model of chronic colonic inflammation. The anti-inflammatory effects of $\mathrm{CO}$ are attributed to the inhibition of GSK-3 $\beta$ signaling and highlight the broad impact of these pathways on intestinal inflammation. GSK$3 \beta$ inhibition correlated with increased IL-10 expression, which may be relevant anti-inflammatory mechanism of this pathway, because IL-10 was reported to have a protective role in colonic inflammation [42]. Also, the balance of cytokines production is controlled with the regulation of Th1 and Th2 profile by $\mathrm{HO}-1 / \mathrm{CO}$ system [22]. In summary, our data demonstrate that $\mathrm{CO}$ decreases inflammatory responses via inhibition of GSK-3 $\beta$ and pro-inflammatory cytokines in DSS-induced colitis. Our mechanism provided in the COinduced protection against DSS-induced colitis might play an important role in the treatment of ulcerative colitis.

\section{Conflict of Interests}

The authors declare that there is no conflict of interests regarding the publication of this paper.

\section{Author's Contribution}

Md. Jamal Uddin and Sun-oh Jeong contributed equally to this work and thus share first authorship.

\section{Acknowledgments}

This study was supported by a Korea Research Foundation Grant funded by the Korean government (MOEHRD), (BRL2009-0087350) and the Bio \& Medical Technology Development Program of the National Research Foundation (NRF) funded by the Ministry of Science, ICT \& Future Planning (2012M3A9C3048687).

\section{References}

[1] C. Fiocchi, "Inflammatory bowel disease: etiology and pathogenesis," Gastroenterology, vol. 115, no. 1, pp. 182-205, 1998.

[2] R. J. Xavier and D. K. Podolsky, "Unravelling the pathogenesis of inflammatory bowel disease," Nature, vol. 448, no. 7152, pp. 427-434, 2007.

[3] T. Lawrence, M. Bebien, G. Y. Liu, V. Nizet, and M. Karin, "IKK $\alpha$ limits macrophage NF- $\kappa \mathrm{B}$ activation and contributes to the resolution of inflammation," Nature, vol. 434, no. 7037, pp. 1138-1143, 2005.

[4] I. Okayasu, S. Hatakeyama, M. Yamada, T. Ohkusa, Y. Inagaki, and R. Nakaya, "A novel method in the induction of reliable experimental acute and chronic ulcerative colitis in mice," Gastroenterology, vol. 98, no. 3, pp. 694-702, 1990.

[5] Y. Yamada, S. Marshall, R. D. Specian, and M. B. Grisham, "A comparative analysis of two models of colitis in rats," Gastroenterology, vol. 102, no. 5, pp. 1524-1534, 1992.

[6] S. W. Ryter, D. Morse, and A. M. K. Choi, "Carbon monoxide and bilirubin: potential therapies for pulmonary/vascular injury and disease," American Journal of Respiratory Cell and Molecular Biology, vol. 36, no. 2, pp. 175-182, 2007.
[7] R. A. F. Hegazi, K. N. Rao, A. Mayle, A. R. Sepulveda, L. E. Otterbein, and S. E. Plevy, "Carbon monoxide ameliorates chronic murine colitis through a heme oxygenase 1-dependent pathway," The Journal of Experimental Medicine, vol. 202, no. 12, pp. 1703-1713, 2005.

[8] S. Z. Sheikh, R. A. Hegazi, T. Kobayashi et al., "An antiinflammatory role for carbon monoxide and heme oxygenase-1 in chronic Th2-mediated murine colitis," Journal of Immunology, vol. 186, no. 9, pp. 5506-5513, 2011.

[9] A. Nakao, H. Toyokawa, M. Abe et al., "Heart allograft protection with low-dose carbon monoxide inhalation: effects on inflammatory mediators and alloreactive T-cell responses," Transplantation, vol. 81, no. 2, pp. 220-230, 2006.

[10] J. Kohmoto, A. Nakao, D. B. Stolz et al., "Carbon monoxide protects rat lung transplants from ischemia-reperfusion injury via a mechanism involving p38 MAPK pathway," American Journal of Transplantation, vol. 7, no. 10, pp. 2279-2290, 2007.

[11] U. Goebel, M. Siepe, A. Mecklenburg et al., "Carbon monoxide inhalation reduces pulmonary inflammatory response during cardiopulmonary bypass in pigs," Anesthesiology, vol. 108, no. 6, pp. 1025-1036, 2008.

[12] G. Cepinskas, K. Katada, A. Bihari, and R. F. Potter, "Carbon monoxide liberated from carbon monoxide-releasing molecule CORM-2 attenuates inflammation in the liver of septic mice," American Journal of Physiology: Gastrointestinal and Liver Physiology, vol. 294, no. 1, pp. G184-G191, 2008.

[13] T. Minamino, H. Christou, C.-M. Hsieh et al., "Targeted expression of heme oxygenase-1 prevents the pulmonary inflammatory and vascular responses to hypoxia," Proceedings of the National Academy of Sciences of the United States of America, vol. 98, no. 15, pp. 8798-8803, 2001.

[14] P. Sawle, R. Foresti, B. E. Mann, T. R. Johnson, C. J. Green, and R. Motterlini, "Carbon monoxide-releasing molecules (CO-RMs) attenuate the inflammatory response elicited by lipopolysaccharide in RAW264.7 murine macrophages," The British Journal of Pharmacology, vol. 145, no. 6, pp. 800-810, 2005.

[15] T. Takagi, Y. Naito, K. Uchiyama et al., "Carbon monoxide liberated from carbon monoxide-releasing molecule exerts an anti-inflammatory effect on dextran sulfate sodium-induced colitis in mice," Digestive Diseases and Sciences, vol. 56, no. 6, pp. 1663-1671, 2011.

[16] A. Ali, K. P. Hoeflich, and J. R. Woodgett, "Glycogen synthase kinase-3: properties, functions, and regulation," Chemical Reviews, vol. 101, no. 8, pp. 2527-2540, 2001.

[17] R. S. Jope and G. V. W. Johnson, "The glamour and gloom of glycogen synthase kinase-3," Trends in Biochemical Sciences, vol. 29, no. 2, pp. 95-102, 2004.

[18] S. Frame and P. Cohen, "GSK3 takes centre stage more than 20 years after its discovery," The Biochemical Journal, vol. 359, no. 1, pp. 1-16, 2001.

[19] B. J. R. Whittle, C. Varga, A. Pósa, A. Molnár, M. Collin, and C. Thiemermann, "Reduction of experimental colitis in the rat by inhibitors of glycogen synthase kinase-3 $\beta$," British Journal of Pharmacology, vol. 147, no. 5, pp. 575-582, 2006.

[20] J. F. Ndisang, N. Lane, and A. Jadhav, "Upregulation of the heme oxygenase system ameliorates postprandial and fasting hyperglycemia in type 2 diabetes," American Journal of Physiology: Endocrinology and Metabolism, vol. 296, no. 5, pp. E1029-E1041, 2009.

[21] T. J. Chambers, J. M. Owens, G. Hattersley, P. S. Jat, and M. D. Noble, "Generation of osteoclast-inductive and osteoclastogenic cell lines from the $\mathrm{H}-2 \mathrm{Kbts}$ 55 transgenic mouse," 
Proceedings of the National Academy of Sciences of the United States of America, vol. 90, no. 12, pp. 5578-5582, 1993.

[22] V. P. Marques, G. M. Gonçalves, C. Q. Feitoza et al., "Influence of TH1/TH2 switched immune response on renal ischemiareperfusion injury," Nephron Experimental Nephrology, vol. 104, no. 1, pp. e48-e56, 2006.

[23] T. S. Blackwell and J. W. Christman, "The role of nuclear factor$\kappa \mathrm{B}$ in cytokine gene regulation," American Journal of Respiratory Cell and Molecular Biology, vol. 17, no. 1, pp. 3-9, 1997.

[24] M. Martin, K. Rehani, R. S. Jope, and S. M. Michalek, "Tolllike receptor-mediated cytokine production is differentially regulated by glycogen synthase kinase 3," Nature Immunology, vol. 6, no. 8, pp. 777-784, 2005.

[25] F. Demarchi, C. Bertoli, P. Sandy, and C. Schneider, "Glycogen synthase kinase- $3 \beta$ regulates NF- $\kappa \mathrm{B} 1 / \mathrm{p} 105$ stability," The Journal of Biological Chemistry, vol. 278, no. 41, pp. 39583-39590, 2003.

[26] A. M. Badger, J. N. Bradbeer, B. Votta, J. C. Lee, J. L. Adams, and D. E. Griswold, "Pharmacological profile of SB 203580, a selective inhibitor of cytokine suppressive binding protein/p38 kinase, in animal models of arthritis, bone resorption, endotoxin shock and immune function," The Journal of Pharmacology and Experimental Therapeutics, vol. 279, no. 3, pp. 1453-1461, 1996.

[27] A. Spittler, M. Razenberger, H. Kupper et al., "Relationship between interleukin- 6 plasma concentration in patients with sepsis, monocyte phenotype, monocyte phagocytic properties, and cytokine production," Clinical Infectious Diseases, vol. 31, no. 6, pp. 1338-1342, 2000.

[28] D. Morse, S. E. Pischke, Z. Zhou et al., "Suppression of inflammatory cytokine production by carbon monoxide involves the JNK pathway and AP-1," The Journal of Biological Chemistry, vol. 278, no. 39, pp. 36993-36998, 2003.

[29] B. A. Moore, L. E. Otterbein, A. Türler, A. M. K. Choi, and A. J. Bauer, "Inhaled carbon monoxide suppresses the development of postoperative ileus in the murine small intestine," Gastroenterology, vol. 124, no. 2, pp. 377-391, 2003.

[30] F. A. D. T. G. Wagener, J.-L. Da Silva, T. Farley, T. De Witte, A. Kappas, and N. G. Abraham, "Differential effects of heme oxygenase isoforms on heme mediation of endothelial intracellular adhesion molecule expression," The Journal of Pharmacology and Experimental Therapeutics, vol. 291, no. 1, pp. 416-423, 1999.

[31] A. Nakao, K. Kimizuka, D. B. Stolz et al., "Carbon monoxide inhalation protects rat intestinal grafts from ischemia/reperfusion injury," The American Journal of Pathology, vol. 163, no. 4, pp. 1587-1598, 2003.

[32] J. S. Neto, A. Nakao, K. Kimizuka et al., "Protection of transplant-induced renal ischemia-reperfusion injury with carbon monoxide," American Journal of Physiology: Renal Physiology, vol. 287, no. 5, pp. F979-F989, 2004.

[33] K. Uchiyama, Y. Naito, T. Takagi et al., "Carbon monoxide enhance colonic epithelial restitution via FGF15 derived from colonic myofibroblasts," Biochemical and Biophysical Research Communications, vol. 391, no. 1, pp. 1122-1126, 2010.

[34] Y. Naito, T. Takagi, K. Uchiyama, and T. Yoshikawa, "Heme oxygenase-1: a novel therapeutic target for gastrointestinal diseases," Journal of Clinical Biochemistry and Nutrition, vol. 48, no. 2, pp. 126-133, 2011.

[35] Y. Xia, J. Rao, A. Yao, F. Zhang, G. Li, X. Wang et al., "Lithium exacerbates hepatic ischemia/reperfusion injury by inhibiting GSK-3beta/NF-kappaB-mediated protective signaling in mice,"
European Journal of Pharmacology, vol. 697, no. 1-3, pp. 117-125, 2012.

[36] C. Platzer, E. Fritsch, T. Elsner, M. H. Lehmann, H. D. Volk, and S. Prosch, "Cyclic adenosine monophosphate-responsive elements are involved in the transcriptional activation of the human IL-10 gene in monocytic cells," European Journal of Immunology, vol. 29, no. 10, pp. 3098-3104, 1999.

[37] X. Hu, P. K. Paik, J. Chen et al., "IFN- $\gamma$ Suppresses IL-10 production and synergizes with TLR2 by regulating GSK3 and CREB/AP-1 Proteins," Immunity, vol. 24, no. 5, pp. 563-574, 2006.

[38] Y.-A. Song, Y.-L. Park, K.-Y. Kim et al., "Black tea extract prevents lipopolysaccharide-induced NF- $\kappa$ B signaling and attenuates dextran sulfate sodium-induced experimental colitis," $B M C$ Complementary and Alternative Medicine, vol. 11, article 91, 2011.

[39] I. Villegas, C. La Casa, A. Orjales, and C. Alarcon de la Lastra, "Effects of dosmalfate, a new cytoprotective agent, on acute and chronic trinitrobenzene sulphonic acid-induced colitis in rats," European Journal of Pharmacology, vol. 460, no. 2-3, pp. 209218, 2003.

[40] T. Takagi, Y. Naito, K. Mizushima et al., "Inhalation of carbon monoxide ameliorates TNBS-induced colitis in mice through the inhibition of TNF- $\alpha$ expression," Digestive Diseases and Sciences, vol. 55, no. 10, pp. 2797-2804, 2010.

[41] K. Sugimoto, A. Ogawa, E. Mizoguchi et al., "IL-22 ameliorates intestinal inflammation in a mouse model of ulcerative colitis," The Journal of Clinical Investigation, vol. 118, no. 2, pp. 534-544, 2008.

[42] D. J. Berg, N. Davidson, R. Kühn et al., "Enterocolitis and colon cancer in interleukin-10-deficient mice are associated with aberrant cytokine production and CD4(+) Th1-like responses," The Journal of Clinical Investigation, vol. 98, no. 4, pp. 1010-1020, 1996.

[43] L. Dugo, M. Collin, D. A. Allen et al., "GSK-3 $\beta$ inhibitors attenuate the organ injury/dysfunction caused by endotoxemia in the rat," Critical Care Medicine, vol. 33, no. 9, pp. 1903-1912, 2005.

[44] P. Cohen and S. Frame, "The renaissance of GSK3," Nature Reviews Molecular Cell Biology, vol. 2, no. 10, pp. 769-776, 2001.

[45] C. Hofmann, N. Dunger, J. Schölmerich, W. Falk, and F. Obermeier, "Glycogen synthase kinase 3- $\beta$ : a master regulator of toll-like receptor-mediated chronic intestinal inflammation," Inflammatory Bowel Diseases, vol. 16, no. 11, pp. 1850-1858, 2010. 


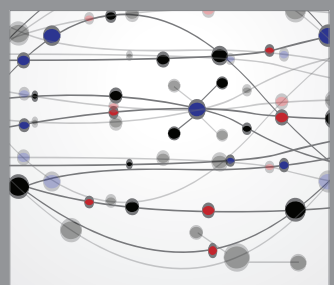

The Scientific World Journal
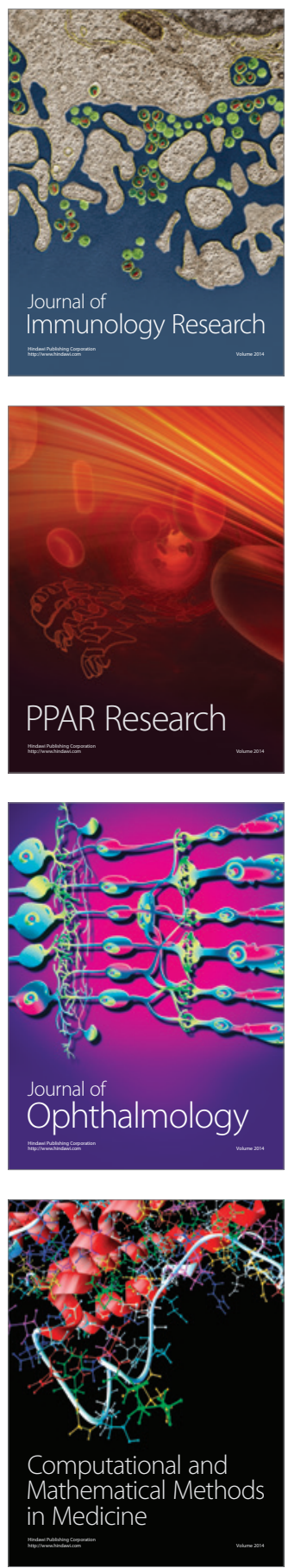

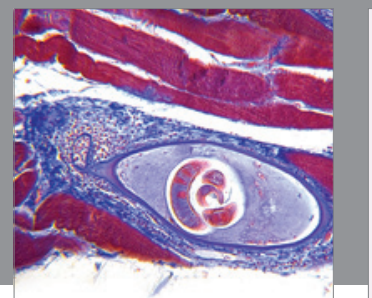

Gastroenterology

Research and Practice
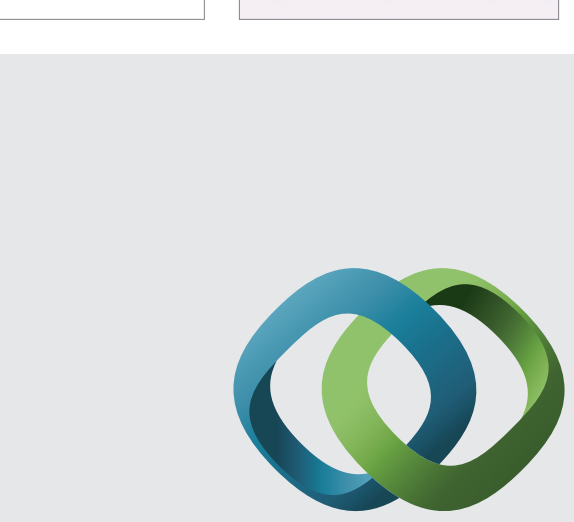

\section{Hindawi}

Submit your manuscripts at

http://www.hindawi.com
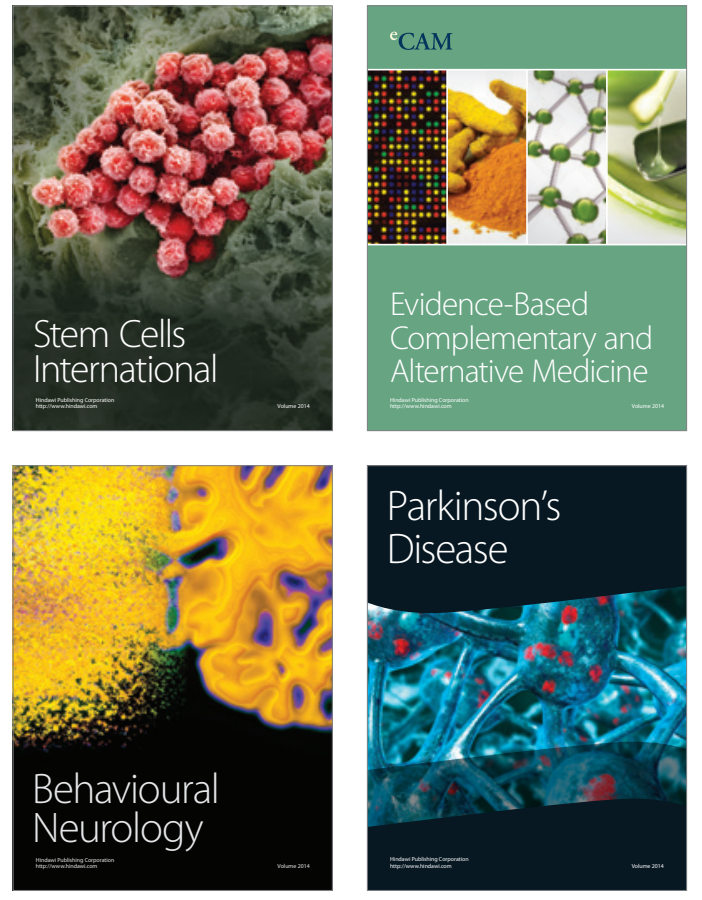
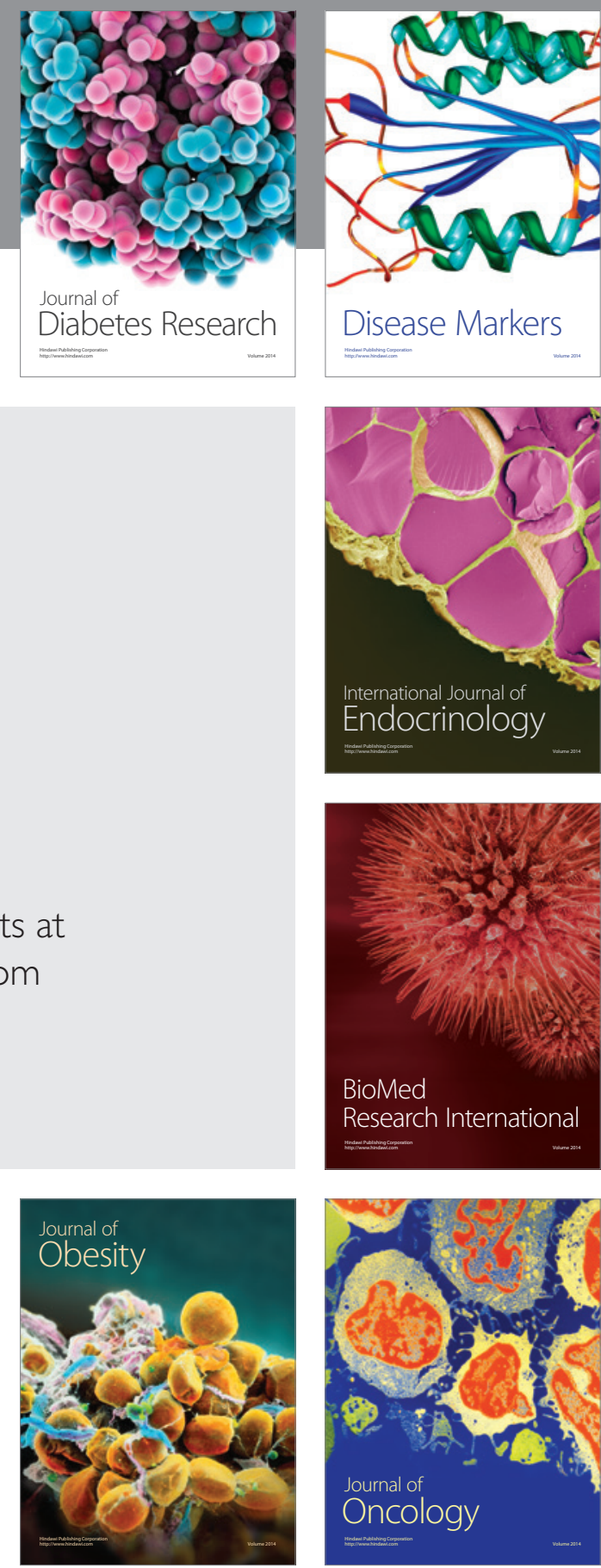

Disease Markers
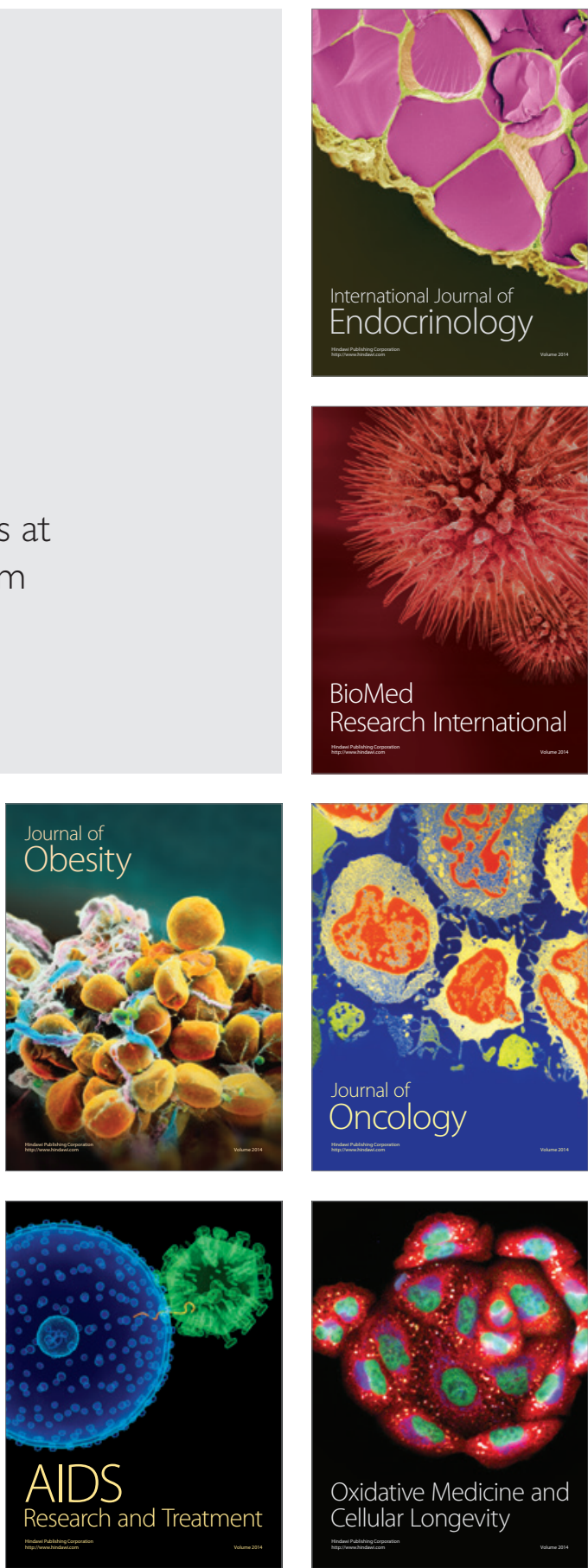